\title{
The Economic Prophesies \\ of George Evan Roberts
}

B. Wylie Anderson

George Evan Roberts was one of Iowa's outstanding public men during the last decade of the nineteenth century and the first four decades of the twentieth, yet today he is little known. He died June 6, 1948 at the age of ninety-one after an active career as journalist, economist, and banker. He was born in Dubuque in 1857 and grew up in Fort Dodge. It was while he was editor of the Sioux City Journal, and editor and publisher of the Fort Dodge Messenger, that Roberts was exposed to the many-sided controversy over the money question -culminating with the defeat of William Jennings Bryan's proposed panacea of free silver in the election of 1896. Roberts wrote a pamphlet berating the "free silver heresy" titled, "Coin at School in Finance," which gained him notoriety with the Repulican Party. In 1897 he was appointed Director of the Mint by the McKinley Administration. After that, Roberts' writings and speeches expressing concern for creation of a sounder banking system attracted nationwide attention.

His interest in Iowa continued while he was in Washington, D.C. In 1902 he and Samuel Strauss, publisher of the Des Moines Leader, consolidated two of the city's daily newspapers into the Des Moines Register and Leader. Harvey Ingham bought eighteen per cent of stock in the newspaper and was hired as editor. After approximately eighteen months, Roberts and Strauss sold fifty per cent of the stock in the paper to Gardner Cowles, Sr., retaining thirty-two per cent. Before long Cowles bought the remaining shares from Roberts and Strauss. 
From 1914 to 1940, while serving as advisor to the president, later as vice president and bank economist of the $\mathrm{Na}$ tional City Bank of New York, Roberts developed a monthly circular letter-the Monthly Letter-delineating his views on economic theory and practice, which came to be highly regarded by businessmen, economists and politicians alike. $-E d$.

"FeW IOWANS NOW LIVING HAVE MORE DESERVEDLY WON and more firmly established a national reputation than has George Evan Roberts." The above statement appears in a reputable 1916 publication. ${ }^{1}$ How soon men and their fame are forgotten. If today you were to ask anyone in Iowa, or the United States for that matter, who George Evan Roberts was they would probably look at you with a blank stare and, more importantly, most of the economists and historians in the state would know nothing about the man with the "firmly established national reputation."

Roberts was indeed a man of many talents: a journalist, a banker, and an economist. His early career was in journalism as a reporter and city editor on the Sioux City Journal. He then became editor and publisher of the Fort Dodge Messenger. His economic interests were brought to the forefront by his successful efforts to fight the "free silver issue," best illustrated by his renown pamphlet entitled "Coin at School in Finance." This led to his active involvement in financial and economic affairs. He was the Director of the U.S. Mint from 1898 to 1907 and from 1910 to 1914 . He served as president of the Commercial National Bank of Chicago (1907 to 1910) and as assistant to the president of that bank from 1919 to 1931 when he became economic advisor, a position which he held till his retirement in 1940. For a two year period (1930 to 1932) he was a member of the Gold Delegation of the Financial Committee of the League of Nations. At his death Emory English eulogized, "[Roberts was] everywhere recognized as the

'Johnson Brigham, “George Evan Roberts," Iowa: Its History and Its Foremost Citizens, 3 (Chicago: S. J. Clarke Publishing Co., 1916), 1771. 
best informed thinker and most convincing speaker on the intricate and confusing questions of the day as they arise in the world of trade and finance." 2

In an obituary in the June 14, 1948 issue of the New York Times entitled "Apostle of Common Sense," Edward Collins said:

... George Roberts was to devote his mature years to the work he loved best and for which he was so admirably equipped-the selfless task of exposing the fallacies, half-truths and misrepresentations which invariably are to be found flourishing like rash weeds in discussions of things economic.

Although never a radical, he was progressive and outspoken as such.

Roberts' main claim to economic prominence no doubt lies in the period that he served as assistant to the president and then as vice president of the First National City Bank of New York. During this period of time he was the editor of their Monthly Letter. It was through this publication (which had a circulation of about 150,000 when he retired) that his ideas as an economist were spread nationally and internationally, and it was here that he quickly acquired an international reputation. His counsel and judgment were sought by bankers, economists, and institutions everywhere. It has been said that Roberts had a way of prophetically anticipating today the problems of tomorrow. "With him the gift of foresight is happily coupled with the wisdom of prepardness." ${ }^{3}$ Another commentator said:

We feel confident, if say a 100 years hence, what Mr. Roberts has set down as sound economic theory should be compared with what others who wrote along economic lines said during the same period, he would find, could he come back to the scene of his activities, that he had less to take back and be ashamed of than any of the economists of the first half of the twentieth century. ${ }^{4}$

It is the purpose of this brief article to investigate the economic ideas of George E. Roberts and determine if today they

${ }^{2}$ Emory H. English, "Capable in Public Service," Annals of Iowa, 29 (October, 1948), 425.

'Brigham, "George Evan Roberts," 1771.

'William R. Boyd, “George Evan Roberts,” Annals of Iowa, 29 (October, 1948), 424. 
are really what his contemporaries said they would be; whether he really had the ability and the foresight to prophesize what would happen in the furure. Was he or was he not a competent economist with a great degree of prophesy?

\section{Money and Purchasing Power}

Seven years before the "Great Crash" Roberts stated that as long as prices are rising (inflation) the more deeply a man goes into debt the more money he is likely to make. However, in going into debt the businessman develops an indifference to debt which leads to very narrow profit margins. This situation soon becomes overweighted on the selling side and prices fall precipitately. ${ }^{5}$ Roberts must have looked into his crystal ball and seen the "Crash" coming because his prediction was, unfortunately, accurate.

The Federal Reserve System had no more ardent supporter than Roberts. It was his belief that the Federal Reserve could control inflation by keeping the supply of money tight, and had it been allowed to do so during the period of 1918-19 the fall of 1920 would not have been so serious. Inflation by means of bank deposits and checks is no different in character from inflation by issues of currency. Roberts and Arthur Burns (current Chairman of the Board of Governors) could change coats on this matter and no one would be able to tell them apart, even though fifty years has elapsed.

As a native Iowan, Roberts carried a life-long interest in agriculture. His belief was that the state of agriculture, in relation to other industries, could not be improved by pumping of fiat money into circulation. The idea that inflation benefits the farmer, as some were claiming in the 1930 s, was totally untrue in Roberts' mind. This was not to say that a normal distribution to farmers does not depend on a rise in prices of farm products. It obviously does depend upon such an increase. However, in the long run agriculture can only exist in harmony with other industries by intelligent and cooperative readjust-

'Roberts' ideas on economic theory and practice examined in this essay are contained in the Monthly Letter of the National City Bank of New York from 1919 through 1930. 
ments in the common interest. The present dilemma in agriculture could be helped by some guidance of this type. Inflation is no better for the farmer than for anyone else.

\section{International Trade and Exchange}

In writing about the fate of Germany in 1919 Roberts puts forth a very good exposition of the theory of comparative advantage which is as valid today as it was in 1919 . He speaks to the fact that the allies had put conditions upon Germany which forced her to fall behind other countries in industrial efficiency and severely handicapped her in her trading relationships with other nations. Much of this action was because the allies feared Germany as a foreign trade competitor. Roberts points out that Germany, while she may be a seller on foreign markets, is also a buyer in the same markets, and if her exports would fall off her imports will likewise fall off. He was saying that there is a presumption of mutual gains in these exchanges which each country voluntarily makes and each country has its own particular products based upon its natural resources and technology which it can render to the world community. He states, "If these are not economic truths there is no science of political economy." The position Roberts put forth in 1919 has been subject to much criticism and abuse by various organizations and governments which have tended to stress periods of isolation in our economic relationships. The current international situation reveals how accurate is the situation where one country is dependent upon another country, sometimes for its very livelihood. Therefore, international trade on an equitable basis is not only desirable but absolutely necessary.

Roberts stressed that the final result of international trade is that both production and consumption shall be on the largest possible scale the world over, and this will lead to a much more widely distributive prosperity and a high standard of living for all peoples. That statement could just as well have appeared in a 1975 economic textbook and in fact does appear in practically all the current principles texts as it did in Roberts' 1919 essay. 


\section{Wealth and Progress}

Stressing the relationship between private and public wealth, Roberts stated in 1918 that property in private hands which has engaged in producing things for the public market is, for all practical purposes, public wealth. It is employed in serving the public and if it was to be taken over by the government it could only go on doing the same thing.

In regard to private profit that accrues from private wealth, most of it is turned back into industry to finance increased production or service. Roberts stated that the public has an interest in these profits that are applied to such purpose. In a statement which is so appropriate that it could have come out of a 1975 newspaper Roberts states, "indeed, it holds the chief interest in them (private profits) in the sense that the railroads are worth vastly more to the public than to their owners." Certainly the people in the state of Iowa, with the current Rock Island disaster, do not need to be convinced that it is the public that suffers as a result of the decline of the Rock Island Railroad, not the private investors alone. In fact, the public may suffer much more than the private investors.

Keynesian economic theory was foreign to Roberts, even though in essence he subscribed to many of the concepts of Keynesian economics. In certain areas, though, he obviously was the typical classical economist and, to that extent, many of the things that he believed in have not turned out to be true. He stressed in 1918 that consumption must equal production. The situation must be at an equilibrium. And he states that in the modern communities it is impossible for the rich to get richer and the poor poorer. Here he was following the neoclassical theory of economics where supply creates its own demand. The Great Depression was to prove that analysis wrong. To that extent Roberts was also wrong following that analysis. However, up until 1936 even Keynes himself had subscribed to Say's Law (which stated that supply creates its own demand).

That politics and the economy should be closely intertwined was a growing part of Roberts' philosophy. As early as 
1924 he envisioned the very close relationship between business, politics, and economics that exists in our current society. He also saw the temptation of competitive promises, "The most appealing of which are promises of benefits by changing the flow of wealth in some manner-redistribution, taxation, restraint, or seizure by interfering in some way with the natural trend or development of affairs." He could foresee the tremendous pressure that would be put on government to continually meet the demands of its constituents in this regard. He also realized that to be properly carried out it required a knowledge of economic principles which in most politicians "are not generally highly developed." He foresaw the close cooperation between political and economic interests in our current system of economic determination.

Roberts would no doubt find fault with some efforts of current farm organizations to restrict production. Writing in 1930 he stated, "Any attempt on the part of government to restrict the production of individual farmers is inconsistent with all its past efforts for the development of agriculture." Roberts is not implying here that there will never be overproduction of farm products in relation to demand. He realizes that there will be. The question he raised was: how should the restriction be applied or distributed? He considers that a fundamental concept in a free society, and is merely saying that the farmer himself should make these decisions. He believes it is utterly impractical for any government to attempt to enforce uniform crop reduction and that a farmer's policy has to be guided by the condition that the farmer experiences as an individual. Obviously he is counting upon the free market to regulate production and as such would have no objection to allowing marginal land and marginal farmers to drop out of production. And to that extent, although he may not agree, he could be put in the camp of those who have no objections to the large corporation farms now developing. In short, he is accepting the law of the survival of the fittest in saying that if it applies to Henry Ford's assembly line then it probably should apply to the management of a herd of dairy cows. He further states 
"The fundamental fallacy in all the so-called farm relief price support programs is in the attempt to deal with farmers in the mass instead of recognizing that inevitably they must prosper or fail as individuals." It is apparent, then, that he was not a believer in a system of price supports; however, although many people today may be friendly to his point of view, government controls and subsidies in the agricultural sector have not shown signs of diminishing.

No one has the ability to look into the future and foretell events. If that is true in general it is even more true in the field of economics. However, George Evan Roberts was a better forecaster of future economic events than most of his contemporaries. His comments on agriculture, railroads, and international trade were particularly perceptive and most apropos to present economic conditions. He was not right all the time, of course, but his contributions to economic theory were significant. Certainly his contributions to the economic policies and guidelines of the National City Bank of New York during his tenure helped set the stage for the progressive nature of that bank in today's financial world.

Roberts spent most of his later life in the East, but he continually returned to Iowa for a "renewing of the spirit," as he called it. His accomplishments are definitely deserving of greater recognition from his native state. It may very well be true, as William Boyd said in assessing Roberts' work, that could he return to the scene of his activities, "he would have less to take back and be ashamed of than any other economist of the first half of the twentieth century." 
Copyright of Annals of Iowa is the property of State of Iowa, by \& through the State Historical Society of Iowa and its content may not be copied or emailed to multiple sites or posted to a listserv without the copyright holder's express written permission. However, users may print, download, or email articles for individual use. 